\title{
Acadiensis
}

Journal of the History of the Atlantic Region

Revue d'histoire de la région Atlantique

\section{"For her own safety and the good of society at large": Eugenics, Sterilization, and Anglo-American Transnationalism in Newfoundland, 1928-1934}

\section{J. T. H. Connor}

Volume 48, numéro 1, 2019

URI : https://id.erudit.org/iderudit/1062177ar

DOI : https://doi.org/10.1353/aca.2019.0002

Aller au sommaire du numéro

Éditeur(s)

Department of History at the University of New Brunswick

ISSN

0044-5851 (imprimé)

1712-7432 (numérique)

Découvrir la revue

Citer cet article

Connor, J. (2019). "For her own safety and the good of society at large":

Eugenics, Sterilization, and Anglo-American Transnationalism in

Newfoundland, 1928-1934. Acadiensis, 48(1).

https://doi.org/10.1353/aca.2019.0002

\section{Résumé de l'article}

Environ la moitié des deux douzaines de femmes qui subirent une stérilisation chirurgicale entre 1928 et 1934 alors qu’elles étaient soignées par des médecins américains qui travaillaient pour l'International Grenfell Association (IGA) à St. Anthony (Terre-Neuve) furent stérilisées parce qu'elles étaient considérées comme mentalement inaptes ou inférieures. Ces stérilisations coïncidaient avec la montée des préoccupations suscitées par les personnes d'esprit faible et des solutions eugéniques et législatives adoptées aux États-Unis, dans l'empire britannique et au-delà. Aucun mouvement eugénique ne vit cependant le jour à Terre-Neuve, qui n'adopta pas de lois pour approuver la stérilisation chirurgicale. Ce qui se produisit à St. Anthony était le résultat de l'américanisation de l'IGA, qui fut par ailleurs bénéfique. 


\title{
"For her own safety and the good of society at large": Eugenics, Sterilization, and Anglo-American Transnationalism in Newfoundland, 1928-1934
}

\author{
J.T.H. CONNOR
}

\begin{abstract}
Environ la moitié des deux douzaines de femmes qui subirent une stérilisation chirurgicale entre 1928 et 1934 alors qu'elles étaient soignées par des médecins américains qui travaillaient pour I'International Grenfell Association (ICA) à St. Anthony (Terre-Neuve) furent stérilisées parce qu'elles étaient considérées comme mentalement inaptes ou inférieures. Ces stérilisations coïncidaient avec la montée des préoccupations suscitées par les personnes d'esprit faible et des solutions eugéniques et législatives adoptées aux États-Unis, dans l'empire britannique et au-delà. Aucun mouvement eugénique ne vit cependant le jour à Terre-Neuve, qui n'adopta pas de lois pour approuver la stérilisation chirurgicale. Ce qui se produisit à St. Anthony était le résultat de l'américanisation de l'ICA, qui fut par ailleurs bénéfique.
\end{abstract}

\begin{abstract}
From 1928 to 1934, about half of the two dozen women who were surgically sterilized while under the care of American doctors working with the International Grenfell Association (ICA) in St. Anthony, Newfoundland, were sterilized because they were deemed to be mentally unfit or substandard. These sterilizations coincided with rising concern about feebleminded persons and eugenic and legislative solutions across the United States, the British Empire, and beyond, but Newfoundland did not develop a eugenic movement nor did it enact laws to sanction surgical sterilization. What happened in St. Anthony was a result of the otherwise beneficial "Americanization" of the ICA.
\end{abstract}

WHEN FORMER US SECRETARY OF STATE REX TILLERSON CALLED his ex-boss President Donald Trump a " $\mathrm{f}^{* * *}$ ing moron," and the latter's tweet taunted him to an IQ test challenge, an unanticipated medical history learning moment presented itself. ${ }^{1}$ While neither of these world leaders likely knew

1 In terms of the spat between Tillerson and Trump, see https://www.theguardian.com/us-news/2017/oct/10/ donald-trump-forbes-rex-tillerson-moron. And apparently media mogul Rupert Murdoch also came to the same conclusion more or less as Tillerson independently; see https://www.cnbc.com/2018/01/07/michael-wolffs-fire-andfury-some-of-the-facts-just-dont-stack-up.html. But in an effort to be fair and balanced, it should be noted that Trump has assessed himself as a genius; see https://www.theguardian.com/us-news/2018/jan/06/donald-trumptweets-mental-stability-fire-and-fury-michael-wolff. To further illustrate just how fine the line is between these topics, the columnist Richard Wolffe has drawn connections between Trump and eugenic thinking; see https://www. theguardian.com/commentisfree/2018/jan/12/racist-in-chief-shithole-countries-donald-trump-bigotry-historicracism.

J.T.H Connor, "'For her own safety and the good of society at large': Eugenics, Sterilization, and Anglo-American Transnationalism in Newfoundland, 1928-1934," Acadiensis 48, no. 1 (Spring/printemps 2019): 32-59. 
the derivation of the term employed, they recognized an insult that referred to presumed stupidity; they also no doubt could have dug deeper into their vocabulary to utter similar terms such as idiot and imbecile. In current parlance, these words are insulting and demeaning because they are hurled as insults intended to demean; this circular, self-referential lexical, and contextual relationship is taken for granted. Few people outside of history of medicine circles, however, understand that in an earlier time such words were diagnostic labels to categorize people medically that resulted in their incarceration or segregation from society. Once segregated, they also might be subject to surgical sterilization. ${ }^{2}$

Rooted as these terms were in early-2oth-century theories of race betterment and feeblemindedness, which essentially justified the culling of the mentally and physically unfit from mainstream society, they had then a technical significance and specificity that was usually linked to catastrophic consequences. Because of the diachronic tension between etymological origins and current context, historians have often gone to great lengths to ensure that readers of their scholarly studies do not misunderstand what they have written when terms such as "moron," "imbecile," "idiot," or "cretin" are used. A feature of recent works, then, is that these words often appear in italics or in scare quotes and/or there might be a "note to readers on terminology" preceding the main text - all this with the intent of distancing the author from any possible misunderstood derogatory or pejorative interpretations. ${ }^{3}$ Another common feature is scholars' national perspective. American studies, for example, address issues of race, class, and gender with particular emphasis on the Deep South and also the West. ${ }^{4}$ Similar issues are to be found in Canadian studies on eugenics and the history of sterilization, where recent studies have drawn attention to the singling out of Indigenous women and girls particularly in western Canada to highlight, at best, implicit or overt state-sanctioned

2 Foundational for understanding the broad parameters of these topics is Alison Bashford and Philippa Levine, eds., The Oxford Handbook of the History of Eugenics (New York: Oxford University Press, 2010). Another informative overview is the PBS documentary film The Eugenics Crusade: What's Wrong with Perfect? (2018), written and directed by Michelle Ferrari; see https://www.pbs.org/wgbh/americanexperience/films/eugenics-crusade/.

3 This and related issues are more fully explored in J.T.H. Connor, "'The 'Human Subject,' 'Vulnerable Populations,' and Medical History: The Problem of Presentism and the Discourse of Bioethics," Canadian Bulletin of Medical History 34 no. 2 (2017): 496-520. I am grateful to the editors of the Canadian Bulletin of Medical History for allowing me to use selected, occasional passages from this methodological essay; see https://doi.org/10.3138/cbmh.34.2.175-25022016. These are reprinted with permission from University of Toronto Press; see https://utpjournals.press.

4 Edward J. Larson, Sex, Race, and Science: Eugenics in the Deep South (Baltimore: Johns Hopkins University Press, 1995); Wendy Kline, Building a Better Race: Gender, Sexuality, and Eugenics from the Turn of the Century to the Baby Boom (Berkeley and Los Angeles: University of California Press, 2005); Alexandra Minna Stern, Eugenic Nation: Faults and Frontiers of Better Breeding in Modern America (Berkeley and Los Angeles: University of California Press, 2005). 
programs of discrimination and, at worst, cultural genocide. ${ }^{5}$ Considered collectively, these recent North American studies refer to events and persons external to their national or regional parameters but they make little overt attempt to be comparative.

A previous generation of scholarship, however, consciously studied eugenics in a transnational context (usually American, British, and Canadian). ${ }^{6}$ Paradigmatic in this regard is Stefan Kühl's comparative analysis of the "Nazi connection" between American racism and German National Socialism through eugenics. Central to this path-breaking work was the use of primary documents outside of the United States to demonstrate how eugenics was imported to Germany and how that affected American thinking on eugenics. Even when writing in 1994, however, Kühl noted that the historiography on eugenics had been "limited by a national perspective. By focusing on eugenics as a national movement and a national science, historians have tended to overlook the issue of international collaboration. Although important recent studies acknowledge the international aspects of eugenics, transnational cooperation has not been adequately explored." In the context of eugenics, words like "collaboration" and "cooperation" might seem jarring - and were usually construed positively - but Kühl's use of them remains apposite. Within North America, one recent study demonstrates how Kühl's critique points the way to a richer exploration of this broad and vexing subject. Leslie Baker examined the evolution of eugenic thought and actions in Nova Scotia for the period 1890 to 1931 ; in particular, she was interested in how "Nova Scotian physicians and philanthropists, with strong ties to both New England and Britain, participated in the transnational eugenic discourse through both professional and popular publications and organizations." ${ }^{8}$ In so doing she demonstrated the ways

5 Recent studies are Erika Dyck, Facing Eugenics: Reproduction, Sterilization, and the Politics of Choice (Toronto: University of Toronto Press, 2013); Claudia Malacrida, A Special Hell: Institutional Life in Alberta's Eugenic Years (Toronto: University of Toronto Press, 2015); and Karen Stote, An Act of Genocide: Colonization and the Sterilization of Aboriginal Woman (Halifax: Fernwood Publishing, 2015). For a more comprehensive historiographic review, see Erika Dyck, "History of Eugenics Revisited," Canadian Bulletin of Medical History 31, no. 1 (2014): 7-16, which is also an introduction to a special journal issue devoted to the history of eugenics.

6 Daniel Kevles, In the Name of Eugenics: Cenetics and the Uses of Human Hereditary (Berkeley: University of California Press, 1986); Pauline M.H. Mazumdar, Eugenics, Human Genetics and Human Failings: The Eugenics Society, its Sources and its Critics in Britain (London: Routledge, 1992); Ian Dowbiggin, The Sterilization Movement and Clobal Fertility in the Twentieth Century (New York: Oxford University Press, 2008).

7 Stefan Kühl, The Nazi Connection: Eugenics, American Racism, and German Socialism (Oxford: Oxford University Press, 1994), esp. xvi-xvii. Also noteworthy with respect to transnationalism and eugenics is Per Anders Rudling, "Eugenics and Racial Biology in Sweden and the USSR: Contacts Across the Baltic Sea," Canadian Bulletin of Medical History 31, no. 1 (2014): 41-75

8 Leslie Baker, "Institutionalizing Eugenics: Custody, Class, Gender and Education in Nova Scotia's Response to the "Feeble-minded," 1890-1931" (PhD diss., University of Saskatchewan, 2015), 13-14; see https://ecommons.usask.ca/ bitstream/handle/10388/ETD-2015-01-1934/BAKER-DISSERTATION.pdf. 
in which one Canadian jurisdiction had been galvanized into action and influenced by American and British thinking. Baker's transnational approach also instructively illustrates how terminology as applied in Nova Scotia moron, feebleminded, etc. - was an inconsistent amalgam of American and British definitions, which also differed among themselves. Most recently and most propitiously, eugenics and sterilization have again been analyzed through the lens of transnationalism as scholars focus on the dominions of Australia, Canada, South Africa, and New Zealand. This scholarship culminated in a collection of essays titled Eugenics at the Edges of Empire, which, as Alison Bashford commented, was "long overdue." Commenting specifically on the connections between eugenics and these "settler-colonies-turned-new-nations," she noted that the "quality and quantity of 'whiteness' was paramount .... Nation-building within a racially alert transnational context is the key context for understanding eugenics in the Dominions. There is thus a particular history of eugenics in this British world." Curiously, another jurisdiction at the edges of empire, Newfoundland, was not included in this volume.

Newfoundland, owing to its previous status as a British colony and then a dominion, was a staunch part of the British empire peopled primarily by those of white Anglo-Saxon stock (and, later, French and Irish); on the Labrador coast, which belonged to Newfoundland, were peoples of mixed European and Indigenous descent, along with those Indigenous peoples themselves. ${ }^{10}$ Owing to crushing debt accumulating during the Depression, the British government in 1934 installed a six-man Commission of Government appointed unilaterally in London to administer all aspects of Newfoundland. The commission was dissolved in 1949 when Newfoundland joined Canada to become its tenth confederated province. ${ }^{11}$ This article focuses on Newfoundland for a six-year period, between 1928 and 1934, and demonstrates how some medical leaders in this British colonial outpost before the Commission of Government entertained eugenic ideas that originated less from the motherland and more from American agents and influences. And what really differentiated

9 Alison Bashford, "Preface," in Diane B. Paul, John Stenhouse, and Hamish C. Spencer, eds., Eugenics at the Edges of Empire: New Zealand, Australia, Canada, and South Africa ([London]: Palgrave Macmillan, 2018), vii.

10 The terminology concerning the Indigenous or Aboriginal peoples of Newfoundland is changing and complex; see http://www.heritage.nf.ca/articles/aboriginal/aboriginal-peoples-introduction.php and http://www.naho.ca/ publications/topics/terminology/.

11 A useful overview is Newfoundland Historical Society, A Short History of Newfoundland and Labrador (St John's: Boulder Publications, 2008); see also Peter Neary, Newfoundland in the North Atlantic World, 1929-1949 (Montreal and Kingston: McGill-Queen's University Press, 1988). For an overview of health care delivery in Newfoundland at this time, see J.T.H. Connor, Jennifer J. Connor, Monica G. Kidd, and Maria Mathews, "Conceptualizing Health Care in Rural and Remote Pre-Confederation Newfoundland as Ecosystem," Newfoundland and Labrador Studies 30, no. 1 (2015): $113-38$. 
Newfoundland and underscored its American eugenic roots from the situation elsewhere in the British Empire was the practice of surgical sterilization. While eugenic thinking and vocabulary was bandied about, Newfoundland had no policy or program regarding sterilization; yet unofficially sterilization was carried out surgically and by other means (radium irradiation) on island women. While other clinical imperatives to operate on these women may have existed, certainly eugenic ideals were the clear and declared motivation in many cases; in some others, the motive was implicit. The number of cases of sterilizations identified in this study is small (about two dozen) compared with the tens of thousands recorded for the United States and western Canada. This small number, however, does not mitigate that fact that sterilizations were practiced - it is their existence, not their frequency, that is important. Moreover, methodologically this discussion underscores the value of studying eugenics from several national vantage points as it demonstrates the utility of a transnational historical perspective.

\section{Race degeneracy, the 1934 Report of the Departmental Committee on Sterilisation, and the Commission of Government}

In 1932 the British minister of health commissioned the Report of the Departmental Committee on Sterilisation. The report is silent about Newfoundland, negative evidence that is itself revealing. This committee, headed by Laurence G. Brock (hence its report is typically called the "Brock Report"), was to examine and report on "information already available regarding the hereditary transmission and other causes of mental disorder and deficiency; to consider the value of sterilization as a preventive measure having regard to its physical, psychological, and social effects and to the experience as to legislation in other countries permitting it; and to suggest what further inquiries might be usefully undertaken in this connection. ${ }^{12}$ In addition to Brock, who was also chairman of the English Board of Control for Lunacy and Mental Deficiency, the committee consisted of Ruth Darwin (a granddaughter of Charles Darwin and a commissioner of the Board of Control), the noted biostatistician R.A. Fisher, and several prominent physicians and medical scientists. Briefly, the report concluded that voluntary sterilization should be legalized in Britain if a person was mentally defective or suffered from a mental disorder, or was believed to be a carrier of a grave disability that

12 Report of the Departmental Committee on Sterilization (London: His Majesty's Stationery Office, 1934), 3; see https:// wellcomelibrary.org/item/b18032011\#?c=0\&m=0\&s=0\&cv=0\&z=-0.2029\%2C0.5375\%2C1.5164\%2C0.7672. 
was transmissible, or likely to transmit a mental disorder or defect; no such legislation, though, was ever enacted..$^{13}$

These overarching conclusions were reached after 36 meetings, the testimonies of 60 witnesses, and the analysis of much statistical material compiled by numerous local health authorities and other agencies. Also central to the report was a review of foreign and dominion jurisdictions that had existing legislation allowing sterilization (for example, Canada, Germany, Denmark, Switzerland, and the United States). Appendix VIII included details of such legislation, along with information pertaining to countries that contemplated passing such legislation (Tasmania, New Zealand, and the remaining Scandinavian countries). ${ }^{14}$ Newfoundland, as noted, was never mentioned in this survey, yet it was consulted. In 1932, Dispatch C. no. 204 between Downing Street and Government House in St. John's noted that the British government requested a response from Newfoundland with respect to the Brock committee's remit. Replying, Governor Sir John Middleton stated that no legislation existed in this regard "nor has any been contemplated."'15

Coincidental to but not directly connected with the formulation of Brock's report were other British government discussions relating to the dissolution of responsible government in Newfoundland and its replacement with an appointed Commission of Government. And yet, curiously, these two large debates intersected. As historical geographer Declan Cullen has argued, permeating talks about the economic and political future of Newfoundland was the trope of degeneracy due to the perceived racial decline of this white, Anglo-Saxon settler colony. When gathering material that would constitute the Newfoundland Royal Commission of 1933 (the Amulree Report), commissioners held closed hearings with Newfoundland doctors among others. These men, as Cullen shows, expressed concern over the occurrence of feeblemindedness and "pauper lunatics" in some parts of the island due to the isolation of settlements and resultant intermarriage within families. Degeneracy from inbreeding was one perceived problem, but so too was that of whites marrying Indigenous peoples along with Anglo-Saxons (e.g., "Scotch")

13 Report of the Departmental Committee on Sterilization, 57.

14 Report of the Departmental Committee on Sterilization, Appendix VIII. For contemporary and later analyses of this report, see Leonard Darwin, "Analysis of the Brock Report," Eugenics Review 26, no. 1 (April 1934): 9-13; C.P. Blacker, "Voluntary Sterilization: The Last Sixty Years," Eugenics Review 54, no. 1 (April 1962): 9-23; Charles Webster, "Eugenic Sterilisation: Europe's Shame," http://groups.csail.mit.edu/mac/users/rauch/nvp/misc/eugenic.html; and Randall Hansen and Desmond King, "Eugenic Ideas, Political Interests, and Policy Variance: Immigration and Sterilization Policy in Britain and the U.S.", World Politics 53 (January 2001): 237-63.

15 Governor's Office, Despatches to the Colonial Office, 8 August, 1932 and 10 September 1932, GN 1/2/0 and CN 1/1/7, The Rooms, Archives Division, St. John's, Newfoundland and Labrador. 
intermarrying with those of French stock. In effect, Newfoundlanders who were deemed to be British and "white" racially were an embarrassment, for they seemed to be more on par with inferior peoples of colour within the rest of the empire. One relief worker was quoted as saying how a "few families will get into a little place and they degenerate and go down and down until they lose all their manhood, self-respect, and all honour." The municipal health officer of St. John's drew attention to intermarriage and inbreeding, which resulted in an increase of "feeblemindedness" in communities. Another physician corroborated this conclusion and the reason for it. All in all, the impression was conveyed that over the centuries the original superior settler population of Newfoundland had slid down the racial hierarchical scale to its present sorry state of colonial degenerates. Ironically, as Cullen also shows, the notion of racial degeneracy might also be invoked to defend Newfoundlanders, albeit in a backhanded way. One impassioned British Member of Parliament from Scotland challenged the Newfoundland Royal Commission and the recommendation to revoke responsible government by reminding his fellow Britons that "these are not coloured people. Perhaps I ought to explain that the natives of Newfoundland are not black men, or yellow, or some inferior breed. These are men of English, Scottish, Irish, and even Welsh descent. And though perhaps some of them have deteriorated, like others, by absence from their own soil, none the less they are people of exactly the same type as those of us who sit in this House." And even within the House of Assembly in Newfoundland, debate on this topic took on explicit racial/racist tones when the prime minister objected to criticism that the retraction of responsible government would lower Newfoundland's administrative status to the "same type of government as is given to niggers." In response, the leader of the opposition countered that there were "blacks and untouchables within the Empire who have more rights to a voice in their own governments than the people of Newfoundland."16

The discourse of eugenics, degeneracy, and what would be labelled euphemistically as "racial hygiene" was clearly in the air and all about. On the one hand, it was discussed at a metaphoric and collective level with respect to Newfoundland; on the other hand, it was discussed at a concrete medical level with respect to those Newfoundlanders deemed to be feebleminded. Yet for all intents and purposes surgical sterilization grounded in eugenic thinking was

16 Declan Cullen, "Race, Debt, and Empire: Racializing the Newfoundland Financial Crisis of 1933," Transactions of the Institute of British Geographers 43, no. 4 (December 2018): 689-702; see https://onlinelibrary.wiley.com/doi/pdf/10.1111/ tran.12229. See also Declan Robert Cullen, "What To do About Newfoundland? Colonial Reconstruction and the Commission of Government, 1933-1941" (PhD diss., Syracuse University, 2013), esp. chap. 3 (quotation on 110). 
not practiced officially in this jurisdiction, perhaps reflecting its ties to British officialdom and sensibilities. In reality, however, it was undertaken owing to strong American influences and connections, particularly in the north of the country. The official position on eugenics and sterilization, then, was at odds with what was actually happening.

\section{Right living and the Anglo-American eugenics connection in Newfoundland}

The concept of the "unfit" and all the intellectual baggage it carried, such as eugenics and its notion of the feebleminded, was, as geneticist/historian E.A. Carlson has understatedly described it, a "bad idea." ${ }^{{ }_{17}}$ But bad idea or not, it became a social movement that attracted many sincere believers who created a broad church; many preached this new gospel of salvation in both Britain and the United States. ${ }^{18}$ But the dynamic amalgam of religion, science, medicine, moral uplift (and panic), social engineering, and societal reform often created strange (and sometimes strained) allies. One example of curious intellectual bedfellows was the inventor of corn flakes and peanut butter, the American John Harvey Kellogg (1852-1943) and the Briton (later Sir) Wilfred Thomason Grenfell (1865-1940). As the historian of religion, science, and medicine Ronald Numbers notes, both men shared multiple similar outlooks. Both were doctors for whom religion was central to their lives: Kellogg grew up in the tradition of Seventh-Day Adventism, while Grenfell was an Anglican who later as a young man became enthralled by the American evangelist Dwight L. Moody. But both Kellogg and Grenfell would spurn evangelism and "turned increasingly" to the Social Gospel and also eugenic thinking. Right living also bound these men: an abstemious lifestyle (eschewing alcohol and tobacco), eating primarily a vegetarian diet, and relentless exercise and activity. Further propelling Grenfell was his championing of the English Victorian ideal of muscular Christianity based on the promotion of, for example, manliness, athleticism, (Anglo-Saxon) patriotic duty, and self-discipline. ${ }^{19}$

17 Elof Axel Carlson, The Unfit: A History of a Bad Idea (Cold Spring Harbor, NY: Cold Spring Harbor Laboratory Press, 2001).

18 Christine Rosen, Preaching Eugenics: Religious Leaders and the American Eugenics Movement (New York: Oxford University Press, 2004); Graham J. Baker, "Christianity and Eugenics: The Place of Religion in the British Eugenics Education Society and the American Eugenics Society, c.1907-1940," Social History of Medicine 27, no. 2 (May 2014): 281-302.

19 Ronald L. Numbers, "The Gospel of Right Living: Wilfred Grenfell's Association with John Harvey Kellogg of Battle Creek," in The Grenfell Medical Mission and American Support in Newfoundland and Labrador, 1890s-1940s, ed. Jennifer J. Connor and Katherine Side (Montreal and Kingston: McGill-Queen's University Press, 2019), chap. 3. 
The physical manifestation of Kellogg's vision of right or biologic living, the Social Gospel, and eugenics was his conglomerate of health and religious business activities based in Battle Creek, Michigan (with satellite operations elsewhere in the United States). Central to all of this was Kellogg's luxurious medical and surgical sanitarium - his "temple of health" - that today could be likened to a grand hotel and spa complex cum hospital. ${ }^{20} \mathrm{He}$ also operated the American Medical Missionary College. Kellogg often referred to his operation collectively as a "University of Health." Supporting and promoting these institutions were magazines published by Kellogg, the Medical Missionary and Good Health. ${ }^{21}$ Beginning in 1914, Battle Creek became the site of several national conferences on race betterment that were organized and sponsored by Kellogg. Kellogg preferred the term "race betterment" to "eugenics," but they were synonymous; he was a believer in the utility of coerced sterilization in support of race betterment. Lectures were presented pertaining to right living, such as the prohibition of alcohol, the deleterious effects of tobacco, the problem of venereal diseases, along with the promotion of child health and so on, but a considerable portion of these proceedings was devoted to out-andout eugenic thought and action: surgical sterilization programs, eugenics and immigration, eugenic investigations and the state, eugenic registries, and race degeneracy. Kellogg himself delivered an address entitled "Needed - A New Human Race." ${ }^{22}$ Kellogg and Grenfell first met in 1906 when the latter visited Battle Creek; their association lasted almost four decades. During these years, Grenfell joined the editorial board of Good Health, while Medical Missionary extolled the virtue of his good deeds. In turn, Grenfell wrote complimentary pieces about Kellogg. During his final year in 1940, Grenfell spent time relaxing with Kellogg at the latter's Florida sanitarium establishment. ${ }^{23}$

In a way, Grenfell's career and accomplishments, while different, reflected those of Kellogg; the names of both men became household words as well. Grenfell built a health empire too, but his enterprise was more humanitarian

20 Patsy Gerstner, "The Temple of Health: A Pictorial History of the Battle Creek Sanitarium," Caduceus: A Humanities Journal for Medicine and the Health Sciences 12, no. 2 (Autumn 1996), which is a whole issue devoted to this topic; see https://archive.org/details/caduceushuman1221996unse. For a satirical/black comedy account of Kellogg and his temple of health, see T.C. Boyle's novel The Road to Wellville (New York: Viking, 1993) and the movie of the same name, which was written and directed by Alan Parker and released in 1994 by Columbia Pictures.

21 On Kellogg, his moral and religious philosophy, and his Battle Creek empire, see Brian C. Wilson, Dr. John Harvey Kellogg and the Religion of Biologic Living (Bloomington: Indiana University Press, 2014) and Howard Markel, The Kelloggs: The Battling Brothers of Battle Creek (New York: Pantheon Books, 2017). 11, 12, 1914 (Battle Creek, MI: Race Betterment Foundation, 1914). The Race Betterment Foundation was formed in 1911 with Kellogg funds. Subsequent conferences were held in 1915 in San Francisco and in 1928, the latter hosted by the Battle Creek Sanitarium. 
than it was entrepreneurial. Grenfell first arrived in Newfoundland in 1892 as a medical missionary with the (later Royal) National Mission to Deep Sea Fishermen, after both qualifying in medicine in London in 1888 and going through an evangelical epiphany. He soon realized that his life's work lay in caring for the bodies and souls of fishermen and their families, especially those who plied the waters around Newfoundland's Great Northern peninsula and the southern coast of Labrador. Establishing a base in St. Anthony, which was the most northern settlement on the island, Grenfell set about founding a network of small hospitals, seasonal nursing stations, schools, an orphanage, and cooperative stores that were connected by hospital ships as floating clinics and by dog sled teams. In 1914, the International Grenfell Association (IGA), a charitable organization run on American foundation principles, was created. Also known variously as the Grenfell Mission or the Labrador Mission, the New York City-based IGA (and its subsidiaries in the US, Canada, Britain, and Ireland) for decades channelled astonishingly large amounts of donated medical and other equipment, clothing, supplies, books, and most of all, money, to St. Anthony. Medical and nursing personnel, along with many squads of volunteer university students, signed up with the IGA. To keep this supply pipeline open, Grenfell continuously undertook a lecture circuit embracing Canada, Britain, and especially America. In particular, the northeastern states of New England with their many Ivy League colleges were always receptive and generous to the needs of the IGA. ${ }^{24}$

Among the many programs the IGA sponsored and encouraged were agricultural reforms, such as growing vegetable gardens and raising goats for their milk. But even these reflected issues of race betterment, for, as one visiting American nutritionist noted, the "children of white races need milk."25 Dr. William R.P. Emerson, professor of pediatrics at Boston's Tufts Medical School and the author of Nutrition and Growth in Children (1922), reinforced

24 Jennifer J. Connor, "'We are Anglo-Saxons': Grenfell, Race, and Mission Movements," in Connor and Side, Grenfell Medical Mission and American Support, chap. 2. On Grenfell, see Ronald Rompkey, Grenfell of Labrador: A Biography (Montreal and Kingston: McGill-Queen's University Press, 2009). See also Wilfred Thomason Grenfell, A Labrador Doctor (London: Hodder \& Stoughton, 1920); this autobiography ought to be read in conjunction with Rompkey, "Elements of Spiritual Autobiography in Sir Wilfred Grenfell's A Labrador Doctor," Newfoundland Studies 1, no. 1 (1985): 17-28, and J.T.H. Connor, "Putting the 'Grenfell Effect' in its Place: Medical Tales and Autobiographical Narratives in Twentieth-Century Newfoundland and Labrador," Papers of the Bibliographical Society of Canada 48, no. 1 (2010): $77-$ 118. Also useful for contextual insight into evangelism, eugenics, and British society at the time of Grenfell's epiphany is Graham J. Baker, "Eugenics and Migration: A Case Study of Salvation Army Literature about Canada and Britain, c. 1890-1921," Canadian Bulletin of Medical History 31, no. 1 (2014): 77-98.

25 Marion R. Mosely, "The Third Year of Health Work," in Among the Sea Fishers 20, no. 3-4 (January 1923): 106-9. For more details of Mosely's work with the IGA, see Gail Lush, "Nutrition, Health Education, and Dietary Reform: Gendering the 'New Science' in Northern Newfoundland and Labrador, 1893-1928" (MA thesis in history, Memorial University of Newfoundland, 2008), 170-7. 
this sentiment when he made clear that the preventive work done for these Newfoundland children, while immediately improving their health, also "means saving the race." ${ }^{26}$

\section{The IGA and the sterilization of hospitalized women, 1928-1934}

The dimensions of such voluntary American philanthropic aid and influence were so large that a curious cultural anomaly arose, symbolized in the fact that many IGA institutions flew both the Union Jack and the Stars and Stripes flags. Although historically Newfoundland was very much "British," an American enclave existed in St. Anthony. Dr. Harry Paddon, an English-trained IGA medical missionary with very British sensibilities who worked primarily on the Labrador coast, recorded in 1928 that "St. Anthony is an American colony. I spent 5 weeks there, and studied it from chimney tops to basement. The medical officers have been American there for over 20 years. Just as U.S.A. is nominally a Democracy but really an Oligarchy, so St. A."27

Generally, such Americanization was beneficial for the communities the IGA served, for it meant that highly trained medical personnel imbued with the latest medical knowledge and techniques practiced in otherwise remote regions. Beginning in 1928, however, one of the most recent medical techniques to make its way that far north was eugenic sterilization, primarily owing to the activities of Dr. Charles S. Curtis (1887-1964). Although Wilfred Grenfell did undertake clinical work, ${ }^{28}$ his fund-raising and public relations engagements typically kept him away from the day-to-day medical management and operations of the IGA; for several decades these duties fell to Curtis. Curtis graduated from Harvard Medical School in 1913, then specialized in obstetrics and gynecology at Boston City and Boston Lying-in Hospital and at Yale University. After attending one of Grenfell's lectures he occasionally visited St. Anthony after graduation, but in 1915 he was induced to stay; in 1917 he was appointed chief medical officer of the hospital there. Upon Grenfell's retirement from the role of superintendent of the IGA in 1934, Curtis succeeded him; he maintained this position until 1953, but continued his association as an IGA board member until death. When a new hospital, funded by the province,

26 William R.P. Emerson, "Child Welfare on the Labrador," Among the Deep Sea Fishers 20, no. 3-4 (January 1923): 106.

27 This quotation is from a letter from Paddon to his wife; see Ronald Rompkey, ed., The Labrador Memoir of Dr Harry Paddon, 1912-1938 (Montreal and Kingston: McGill-Queen's University Press, 2003), xxx.

28 On Grenfell as a clinician, see J.T.H. Connor, "Sir Wilfred Thomason Grenfell: Legendary Physician in Newfoundland and Labrador," Hektoen International: A Journal of Medical Humanities (Fall 2016), http://hekint.org/sir-wilfred-

thomason-grenfell-legendary-physician-in-newfoundland-and-labrador/. 
was opened in St. Anthony in 1968 - which still functions - it was named after Curtis to recognize his half-century of service to the IGA. ${ }^{29}$

The late 1920 s was an important period for eugenics in America. At one level, Henry H. Goddard's Feeble-Mindedness: Its Cause and Consequences, was yet again republished; it was first published in 1914, with republication in 1920 and 1926. Curtis would no doubt be aware of this book along with the eugenics debate, especially given Grenfell's apparent sympathies and associations with it. Almost certainly and perhaps more importantly, as an American surgeon who specialized in obstetrics and gynecology Curtis would have known about the decision made by the United States Supreme Court in 1927 that involuntary sterilization was not unconstitutional. Oliver Wendell Holmes, on behalf of the court, wrote how it was "better for all the world, if instead of waiting to execute degenerate offspring for crime, or to let them starve for their imbecility, society can prevent those who are manifestly unfit from continuing their kind. The principle that sustains compulsory vaccination is broad enough to cover cutting the Fallopian tubes." ${ }^{30}$ And this was also a crucial year for the IGA, for a new, larger, fully modern hospital opened in St. Anthony. It was one of only two Newfoundland hospitals to be fully accredited by the American College of Surgeons; the majority of rural hospitals across America failed to achieve this designation. It could accommodate more patients and undertake more complex surgical procedures than its institutional predecessor..$^{31}$

The confluence of these events facilitated Newfoundland's first foray into surgical eugenic intervention. In February 1928 a woman of about 24 years of age was admitted to the St. Anthony Hospital with a septic little finger as result of a kitchen knife wound she incurred in her domestic work. She was a "hired girl" and worked as a domestic servant in an isolated island community off the Labrador coast. The wound was incised, drained, and irrigated; within a few days the infection had not spread and the patient was then discharged and treated in the Out-Patient Department for dressings. The details of the case are not in any way remarkable, but the attending doctor, Curtis, noted on her hospital admission record (a collection of loose-leaf files containing a patient's clinical information and data) that she was "mentally dull." In June of the same year this woman was back in hospital although she was not suffering

29 Bert Riggs, "A Commitment to the North," http://ngb.chebucto.org/Articles/north.html.

30 Philip R. Reilly, The Surgical Solution: A History of Involuntary Sterilization in the United States (Baltimore: Johns Hopkins University Press, 1991), 87.

31 J.T.H. Connor, "American Aid, the International Grenfell Association, and Health Care in Newfoundland, 1920s-1930s," in Connor and Side, Grenfell Medical Mission and American Support, chap. 10. 
from any complaint; Curtis described her as a "white woman ... apparently not at all ill." Indeed, a thorough physical examination conducted indicated that she was in good health: her hearing and vision were good; head, negative; chest, negative; heart, negative, lungs, negative; abdomen, no pains; genitalia, externally negative and her menses were regular and recent. Although she had no history of sore throats, one of her tonsils was enlarged and likely infected and, as was normal for the era and place, about five of her teeth were badly decayed. Noteworthy, however, was her family and personal history, which relayed that her father, mother, brother, and sister were all dead from unknown causes and that she had been a resident of the orphanage run by the IGA.

Despite being an adult and employed as a domestic servant, she was identified in her medical file as a "ward." Curtis's overall clinical impression of the patient was of "Mental Deficiency, Decayed Teeth \& 'Doubtful Tonsils'." Based on this assessment, he decided that "for her own safety and the good of society at large it is advisable to render her incapable of becoming pregnant, and so has ordered her to the Hospital for a sterilizing operation." Within a couple of days, on 8 June 1928, the woman was duly prepped with surgical iodine and anesthetized with ether in order that an "exploratory laparotomy" be conducted. A mid-line incision was made to open her abdomen, "with the intention of sterilizing the Patient," but on close internal inspection a "very small infantile uterus" was observed. The small size of the organ made it impossible to elevate and, owing to the underdeveloped state of the uterus, Curtis concluded that the "Patient is probably sterile any way" whereupon he closed up the abdomen. As the patient was still anesthetized he proceeded to remove 11 teeth that were decayed. Ten days later the abdominal wound had healed, and the patient was discharged from hospital. The clinical record makes no mention of any discussion with the patient before or after the operation concerning its nature or consequences. ${ }^{32}$

The following August, a 37-year-old woman was admitted as she was soon going to give birth. In addition to a diagnosis of pregnancy, however, was another also by Curtis of "potential insanity." When aged seventeen she had spent three months in an insane asylum; ten years later she was "insane again" for six months but stayed at home. She had six children already, three of whom were well, but one other suffered from "fits" while the two others had died of

32 International Grenfell Association, St. Anthony Hospital, admission records \#6088 and \#6187, Charles S. Curtis Memorial Hospital, Labrador-Grenfell Regional Health Authority, St. Anthony, NL. The hospital admission records on which this research is based were redacted to anonymize them so this author has no knowledge of the names or identities of the patients discussed; the digitization of these records, funded in part by CIHR HOM Grant 98740, 
"convulsions." In early September she gave birth to a "normal" boy, while a month later she was operated on for multiple reasons, including repair of a laceration of the cervix, excision of an ovarian cyst, an appendectomy, and sterilization by a double tubal ligation. She was "discharged well" in midNovember after a hospital stay of three months. Again, there is no record if the woman was informed or understood the consequence of the sterilizing procedure. In this case, there is no overt justification on eugenic grounds for sterilizing the patient, but Curtis's case notes, which included a diagnosis of "potential insanity" along with the history of children dead from convulsions and another living but suffering from fits, resulted in a picture of a woman who was biologically unfit and who should no longer be able to procreate. ${ }^{33}$

Another sterilization case began with a 20 -year-old woman being admitted for pregnancy in March 1931. She had been married for two years and had previously given birth, but this premature child had died after one week. In 1931 she was perhaps six months pregnant but was not sure, for as Curtis recorded: "Patient is so retarded mentally that it is impossible to get any definite information from her." Her home living conditions were described as being the "depths of poverty." Two months later she was readmitted and gave birth, but only after a lengthy period (40 hours) of labour and one requiring high forceps to effect the delivery. In March 1932, after slipping on ice and injuring herself she was transported by dogsled to hospital; she was also fivemonths' pregnant. Four months later this now 22-year-old woman, who Curtis again deemed to have a "low order of intelligence (a moron)" with a "very poor memory, and answers all questions with a considerable delay, and difficulty," was readmitted to hospital. Summing up the case, Curtis stated how, in view of the "patient's mental retardation, plus the funnel type of pelvis, and the isolated life she leads," a caesarean section and sterilization were to be performed. Immediately after a caesarean birth of an apparently healthy child, another American IGA doctor, Dr. Robert H. Goodwin, sterilized her. Goodwin first studied at Princeton University and then graduated from Harvard Medical School in 1929 with a specialization in obstetrics and gynecology. While with the IGA (at various times between 1932 and 1934), he practiced in St. Anthony, Cartwright (in Labrador), and also Twillingate (a non-IGA hospital).34

was done by John R. Matchim, who prepared, redacted, and retrieved these electronic documents and this author is grateful for his assistance. 


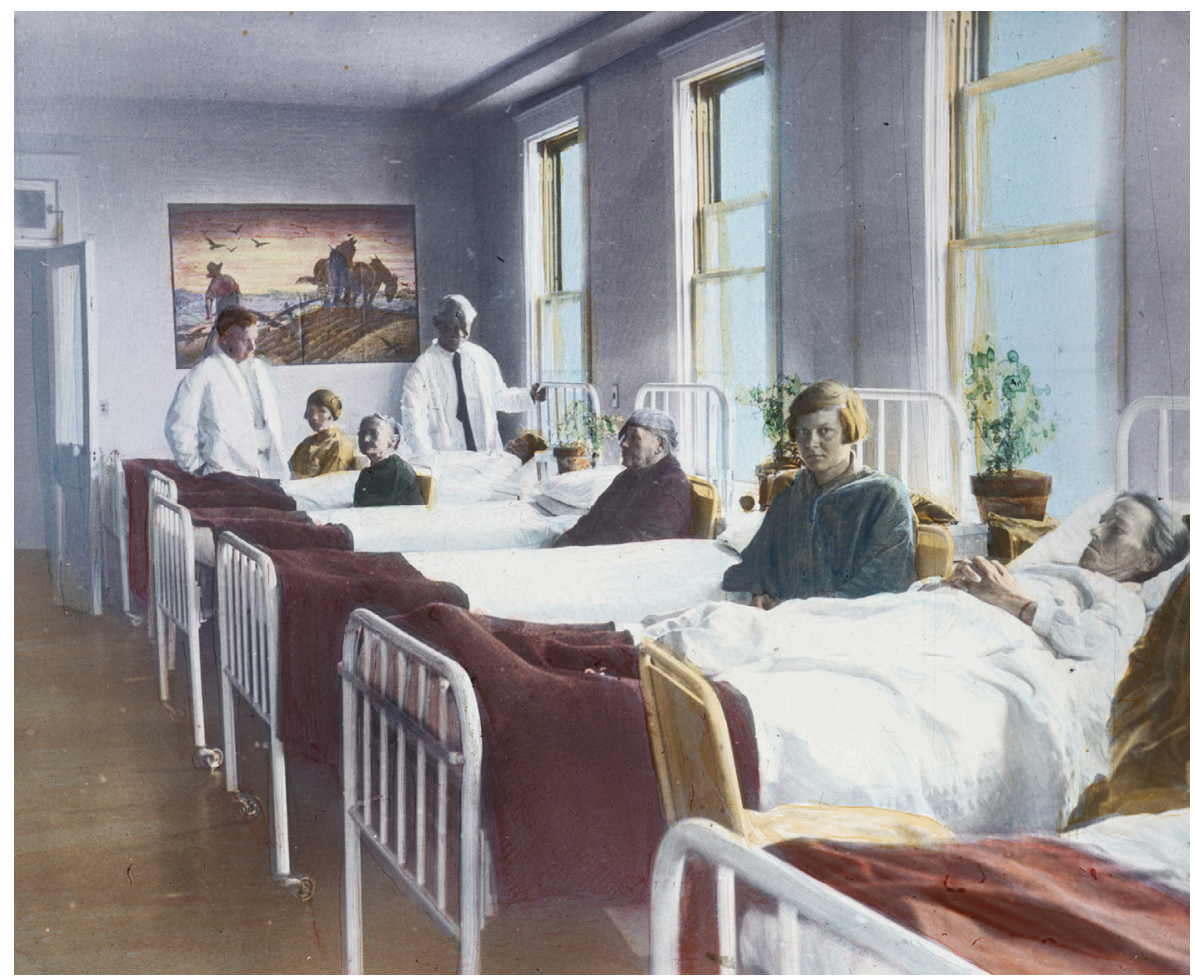

Seven more unambiguous cases of eugenic sterilization were recorded from 1928 until 1934. Two involved patients identified as "schoolgirls" - one aged 16, the other 15. The former was a resident of the IGA orphanage in St. Anthony, who may have suffered from appendicitis. According to Curtis, "Mentally she is apathetic and rather dull. She has been sent to school but over a period of years has not been able to learn to read or write." She was generally in good health, "buxom," and well nourished, but presented with "some vague abdominal complaint." Forthwith, Dr. Goodwin performed an appendectomy and surgical sterilization. After three weeks in hospital she was "discharged well." ${ }_{35}$ The second schoolgirl also complained of an abdominal pain, but her case file noted that an "accurate history cannot be obtained because of the low mentality of the patient." She was further described as a "fairly well nourished girl ... in no apparent physical distress. Extremely dirty." Two days after being admitted to hospital, she had her appendix removed; she 
also underwent a double tubal ligation, despite that during the operation both tubes were observed to be "normal." Two weeks later she was discharged in "good condition." ${ }^{36}$ Both procedures on this girl were performed by Dr. John Steele, yet another visiting American house surgeon and described as an "outstanding example of single-minded devotion to the welfare of the patients .... A voluminous reader of medical journals, he kept completely up-to-date in methods of diagnosis and treatment . . . [and was] a man of few words." ${ }^{37}$ That these surgical sterilizations of minors were prompted by eugenic motives seems incontrovertible. The patients at the time were reported as generally being in good health, noting some indeterminate abdominal complaints. The common factor and predisposing reason for them to be sterilized was their "dull" or "low mentality." Such evaluations of their mental incapacity, however, in the absence of additional clinical information as to how these decisions were arrived at, must be considered to have been even more subjective and arbitrary than the norm.

The justification for surgery in the remaining five cases also hinged on some aspect of patients' mental health and/or capacity. The baldest statement was Curtis's diagnosis of "Mental Deficiency" for a woman (or perhaps a girl) of unidentified age; he noted "Patient has had one illegitimate child. Is a moron." A salpingectomy (total removal of the Fallopian tubes) was quickly performed ${ }^{3}$ In another case, a 32-year-old woman admitted for pregnancy but who also had a medical history of "hysteria" gave birth to an apparently healthy baby by caesarean section but was also surgically sterilized. ${ }^{39}$ Another patient, for whom an "Accurate history is difficult to obtain because of [her] low mentality," had had multiple pregnancies many of which went full term but the babies were stillborn; she had also miscarried. In this case Dr. Steele performed a double tubal ligation, along with an ovariotomy. ${ }^{40}$ Steele also sterilized, among other procedures (including a hemorrhoidectomy and repairing a lacerated perineum), a woman who was admitted for "womb trouble" - likely the patient's own term. Whether Steele had some idea that the woman's mental state might be questionable is not recorded, but during her hospital stay she developed a "manic psychosis" and became restless and

36 International Grenfell Association, St. Anthony Hospital, admission record \#9814.

37 Charles S. Curtis, "Activities at St. Anthony in 1934," Among the Deep Sea Fishers 33, no. 1 (April 1935): 5.

38 International Grenfell Association, St. Anthony Hospital, admission record \#9984.

39 International Grenfell Association, St. Anthony Hospital, admission record \#10037.

40 International Grenfell Association, St. Anthony Hospital, admission record \#10318. 
"talked and sang incessantly with constant references to religious matters." She also had seen a vision. ${ }^{41}$

The final case of this particular group extends the notion of societal moralism as a factor in the narrative of eugenic sterilization in Newfoundland while it introduces yet another complicating one: race. This is also a particularly sad story as reconstructed through 13 years of hospital records based on numerous hospital stays. In 1919, a teenage girl from the IGA orphanage was admitted to hospital also in St. Anthony for an infection on her face; previously, she had contracted diphtheria, pneumonia, and influenza. She was described as having clean hair and deaf in both ears, but could hear if spoken to in a loud voice within ten feet of her. Her face infection cleared up. Two years later she had her tonsils and adenoids removed, which was an extremely common occurrence. At this time she was noted to adhere to the Church of England. Around 1925 she left the orphanage, but continued to live in St. Anthony. In early July 1928, aged 26 , she was again admitted to hospital as she was pregnant. On this occasion she was described by Curtis as a "half-breed eskimo with no morals." Moreover, Curtis continued that the patient herself admitted that "for the past year ... she has had intercourse with practically every person who asked her, boys and men." On the same day she was admitted, she gave birth to a "normal" male baby. Two weeks later she was discharged from hospital in good health; but three weeks after that she was readmitted. During this stay she was sterilized by having both Fallopian tubes removed..$^{42}$

Whether this person's sexual promiscuity was a source of income and support or perhaps a form of mental disease is not known, but it would appear that she continued in this behaviour. In November 1934, two men being treated in hospital for gonococcal venereal disease identified her as the source. At this time she was contacted then again admitted to hospital, where a positive cervical smear confirmed she was infected. Although now an adult and a mother, she was written up as being a "half breed girl of 33." To try to eliminate the infection in an era before antibiotics, and even an era before sulfa drugs such as Prontosil, she was subject to a daily regimen of carbolic, alcohol, and permanganate solution soaked packs that were

41 International Grenfell Association, St. Anthony Hospital, admission record \#10046.

42 International Grenfell Association, St. Anthony Hospital, admission records \#2907, \#3683, and \#5246. Curtis's use of the phrase "half-breed eskimo" as an identifier is as confusing as it is problematic. While it might have been acceptable in its day even by persons of mixed heritage, it probably still was meant to be derogatory when used by him. Certainly, the use of the word "eskimo," while shunned today in Newfoundland and Canada (see note 10), would have been in use during Curtis's era - and of course as an American it would be a natural term to employ, as it still is today (viz. Alaska). As it would be anachronistic and/or imposing today's values on the past to replace Curtis's phrase with currently acceptable terminology, I have chosen not to do so. 
inserted vaginally. Following this treatment she underwent a hysterectomy and oophorectomy to remove her uterus and ovaries, respectively. One week later, she was again operated on for an hemorrhoidectomy. Following the second operation she began vomiting and developed peritonitis and pneumonia. Her condition deteriorated and she died on 6 December, less than one month after she had been admitted. ${ }^{43}$ There was no mention of the fate of her son - presumably he might have been admitted to the orphanage, like his mother before him.

This case invites commentary in several regards. Although she had been in hospital twice when a minor, curiously her racial status only was identified on records after she left the orphanage and in the context of her aberrant behaviour. Moreover, it is difficult not to consider the term "half breed" as anything but derogatory - especially within the context of the two instances quoted. While no mention was made of the woman's mental health or capacity, presumably Curtis would have regarded them as questionable on numerous implicit grounds thereby justifying sterilization: being partly of Indigenous blood she would be assumed almost by definition to be simpleminded; her hearing defect was not only a physical disability, but possibly it may have adversely affected her speech and learning skills rendering her apparently feebleminded; her sexual promiscuity and immorality certainly would have labelled her as degenerate; and being an active source of venereal disease also would have added to her degeneracy. Finally, while illegitimacy was common, to have borne a child under circumstances where presumably the father was unknown and could have been any one of a number of "boys and men" added to her immorality and degenerate status. Gerald O'Brien's study of the metaphors applied to the eugenic category of the "moron" to dehumanize and stigmatize is apposite in this case. He identified five such metaphors: the moron as a diseased entity, an atavistic subhuman, an enemy force, an immoral sinner, and a poorly functioning human. ${ }^{44}$ From a eugenics perspective it can be seen how this woman, although never actually labelled a moron per se, would have been understood as one in almost all these ways.

Two further groups of sterilization cases have been identified from extant St. Anthony hospital records. One, consisting of 11 cases, is characterized by not displaying any connection to eugenics. Typically, a diagnosis of retroversion

43 International Grenfell Association, St. Anthony Hospital, admission record \#10379.

44 Gerald O'Brien, Framing the Moron: The Social Construction of Feeble-mindedness in the American Eugenic Era

(Manchester: Manchester University Press, 2015). 
of the uterus or a similar condition is listed (for example, prolapsed uterus). The women in this group ranged from 19 to 48 years of age and usually complained of longstanding pain or discomfort, especially after childbirth. Presumably, these women availed themselves of medical aid voluntarily in the hope of relief; that is, any surgery performed would have been, in current terms, elective. During the operation to correct the chief complaint often the appendix was removed as a preventive measure, which was not unusual as acute appendicitis would often prove fatal given the remote living conditions of many patients (including males). A more moot question relates to the fact that surgical sterilization of these patients was also performed at the same time. It is plausible that this procedure was undertaken only for the benefit of the patient in order to minimize any future discomfort or problem, with no social agenda as such being followed. ${ }^{45}$ If so, then the need to differentiate the intent and purpose behind any particular example of surgical sterilization is highlighted.

Another issue is the extent to which any woman operated upon was cognizant of the procedure and its consequences. This issue was raised above, but the material contained in the final group of cases allows some elaboration on it. In 1929, a 43-year-old woman was advised by Curtis that sterilization was recommended. ${ }^{46}$ Of all the cases examined, this one is the most complete with respect to illustrating that this procedure might be explained and negotiated. Curtis recorded that the "patient's symptoms have mostly to do with when she is carrying a baby, at which time she is laid up with bearing down pains and unable to work. As she has already had a large number of children and is about at the menopause, it was explained to her that she needed to be sterilized but she did not wish any cutting operation." As result of the patient's request, Curtis resorted to sterilization through the use of a capsule of radium inserted into her uterus. This was a recognized procedure in lieu of a surgical intervention. ${ }^{47}$ Another case of sterilization of a woman with incurable tuberculosis by irradiation was recorded in $1934 \cdot{ }^{48}$ Further evidence that a woman could have agency under such circumstances was a case in which the patient, after being advised by Curtis about sterilization, "flatly refused and

\footnotetext{
45 International Grenfell Association, St. Anthony Hospital, admission records \#8758, \#9017, \#9303, \#9365, \#9483, \#9631, \#9856, \#9961, \#10305, \#10310, and \#10330.

46 International Grenfell Association, St. Anthony Hospital, admission record \#6879.

47 The use of radium in this context at this time was novel, but accepted; see, Palmer Findlay, "Pelvic Irradiation in the Child-bearing Woman," Journal of the American Medical Association 95, no. 12, (1930): 857-60. The more remarkable thing is that radium was available for treatment in St. Anthony, which was also the result of American largesse; see J.T.H. Connor, "American Aid, the International Grenfell Association, and Health Care," in Connor and Side, Grenfell Medical Mission and American Support, chap. 10 
insists on going home with her husband on the next boat."49 As far as can be determined, however, these two examples were exceptional.

\section{Assessing eugenics in Newfoundland: The official perspective and the view from the ground}

The government of Newfoundland's official response to the Brock committee indicated that no legislation regarding eugenic activities existed or was contemplated. From this statement it would be reasonable to conclude that any categorization and/or control of the unfit, the feebleminded, or the mentally deficient would fall to traditional gatekeepers such as asylum personnel using traditional methods of incarceration and restraint; broadly stated, eugenics was not officially practiced in Newfoundland.$^{50}$ As this discussion has shown, however, it certainly was pursued. There was nothing deceptive with respect to the discrepancy between the official view and reality, for it is perfectly safe to assume that political personnel in the capital of St. John's were wholly ignorant of the Americanized ways and doings of those in distant St. Anthony. Although the IGA received a modest annual operating grant from the Newfoundland government, it was in effect a private independent organization due to the generous funds it received primarily from Americans. As such, it was generally the object of benign neglect by the Newfoundland political establishment. Conversely, those in St. Anthony looked upon their medical colleagues and the official administration in St. John's with a certain degree of disdain; that southern port city was useful primarily only as a boarding point for steamer travel to Boston and the New England states. Given these particular geopolitics, that eugenics was practised becomes explicable.

For his part, Wilfred Grenfell as patriarch of the IGA appears never to have operated on any woman that underwent sterilization; that he was not directly connected to any eugenics-inspired surgical activities seems to be the case. During the period of this study, when Curtis and his American colleagues started to perform surgical and other forms of sterilization on women, Grenfell was in his late sixties and had all but retired medically; it is entirely conceivable that he was unaware of these activities. Yet owing to his association with J.H. Kellogg, along with his own views on race betterment, it was most likely that he created an organizational culture that was hospitable

49 International Grenfell Association, St. Anthony Hospital, admission record \#8911.

50 There was only one institution for the mentally ill in Newfoundland, which was located in St John's; see Patricia O'Brien, Out of Mind, Out of Sight: A History of the Waterford Hospital (St John's: Breakwater Books, 1989). 
and encouraging to eugenic ideology. In 1922, for example, in the official IGA magazine Among the Deep Sea Fishers, he himself wrote how after study of the "eugenic researches of the sociologists" it is easy "to conclude that to prolong life in moral defectives is logically indefensible." ${ }^{11}$ And in his many lectures and in his writings Grenfell constantly was a booster of the white, English-speaking Anglo-Saxon race (of good British stock). The use of this trope resulted in a deep affinity with his audiences, who in turn generously supported the IGA.52 This was ironic, of course, as Grenfell also exploited "the North" - that is, northern Newfoundland and coastal Labrador - as the land of the Eskimo, polar bears, icebergs, dogsled teams, and so on as a rugged and exotic locale so as to promote his medical mission and fund-raising activities.53

While only 23 cases of sterilization in St. Anthony have been identified out of a total of 4,114 hospital admission records between 1928 and 1934, this time period was significant. The year 1928 was pivotal in the history of eugenics in North America, and it can be stated with considerable certainty that no sterilization procedures were performed in St. Anthony before this time. The year 1934 is more arbitrary, as it coincides with the publication of the British Brock Report in 1934, Dr. Charles Curtis becoming superintendent of the IGA, and the extensive change in the administrative structure of Newfoundland through the appointment of the Commission of Government. It is possible that further cases of sterilization might be identified in the years following $1934 .{ }^{54}$ Of the 23 identified cases of sterilization, just over one-half were performed on girls and women who were deemed to be eugenically unfit. Persons in this latter group were aged from 15 years to 40 years (the average age was 26 years); descriptions by attending physicians such as "low mentality," "mentally dull," "mentally deficient," "moron," "no morals," and "for the good of society" leave little doubt as to the motivation behind the decision to operate, especially as most of these persons were reported to be otherwise in good health. This

51 Wilfred T. Grenfell, "A New Year Message - The Joyous Venture Called 'Life'," Among the Deep Sea Fishers 19, no. 4 (January 1922): 111.

52 Jennifer J. Connor, "'We are Anglo-Saxons'," in Connor and Side, Grenfell Medical Mission and American Support, chap. 2.

53 See, for example, illustrated books written by Grenfell, such as Down North on the Labrador (New York: Flemming H. Revell, 1910), Down to the Sea: Yarns from the Labrador (London: Andrew Melrose, 1910), and Tales of the Labrador (Boston: Houghton Mifflin Company, 1916).

54 In 1936, three more surgical sterilizations were performed, but clinical information provided in the files suggests that such operations related primarily to painful gynecological conditions; it is noteworthy, however, that two of these women had already borne 11 and 12 children, respectively, and thus might have willingly entertained such a procedure; see International Grenfell Association, St. Anthony Hospital, admission records \#11505, \#11566, and \#11624. A more questionable case occurred in 1937, when a 19-year-old woman gave birth but reported while in hospital that she came from a family in which tuberculosis was rife; at this time she was also diagnosed as recovering from the disease. Her file concluded that she should receive plenty of bed rest and be "prevented from having 
sterilization of women in northern Newfoundland was emphatically neither a grassroots nor an elitist movement - it can best be described as an isolated action. It was imported by resident and visiting American doctors with American medical knowledge, skills, values, and ideals. Inasmuch as they could practice medicine more or less untrammelled in a remote region, the importation and implementation of eugenic-based surgery was just another element of their more or less self-regulated, generally well-meaning, panoply of clinical activities. 55

Is it possible, then, to explain the actions of Curtis and his colleagues without apparently excusing them? In the first case cited here, Curtis wrote in his notes that the surgical sterilization procedure was not only for the good of society but also for his patient's own safety because of her perceived diminished mental capacity. In another case, he cited the patient's isolated residence and living arrangements. Taking these statements at face value, they are expressions of concern grounded in the belief that these women were vulnerable and could realistically have become pregnant against their will. If so, Curtis did have the welfare of his patients in mind albeit paternalistically (the norm at the time); but such concern had draconian consequences. Yet if that was the case, why did he not communicate his intentions and the rationale to them so that they were informed? It is possible, on the one hand, that a patient would not have understood owing to her purported limited intellectual understanding of matters. On the other hand, knowledge that a woman was incapable of ever conceiving might well have made her more vulnerable to assault. Similarly, a woman's sterility might have led to sexual promiscuity, which was immoral. Thus, as far as can be discerned, she may not have been informed in an effort

further children .... Patient has been advised to return for sterilisation and she has promised to do so." In this case, sterilization might have been recommended to curtail endemic family disease, which could be seen as having eugenic overtones; it also might have been suggested to save the woman's life as further childbirth might have been detrimental due to her tuberculous condition; see International Grenfell Association, St. Anthony Hospital, admission record \#11980.

55 Another American medical enclave existed to the southeast of St. Anthony in Twillingate, which was the location of the Notre Dame Bay Memorial Hospital (NDBMH). The NDBMH was not an ICA institution, but its origins were linked to it became it was staffed by American doctors who typically were Johns Hopkins University graduates. The Stars and Stripes also flew over the hospital grounds. As far as can be determined, hospital records for the period under study do not exist; but an exhaustive report of hospital activities for the year 1933 exists. As we have seen, surgical procedures might be performed on women that rendered them sterile but for reasons other than eugenic ones. Nevertheless, this report for the NDBMH recorded that in 1933 alone 32 tubal ligations, 16 hysterectomies, and 22 oophorectomies had been performed. See J.T.H. Connor, "The Notre Dame Bay Memorial Hospital, Twillingate, 1933: An Institutional Profile in a Time of Transition," Newfoundland and Labrador Studies 28, no. 2 (2013): 293-330; J.T.H. Connor, '". . . medicine is here to stay': Rural Medical Practice, Frontier Life, and Modernization in 1930s' Newfoundland," in Medicine in the Remote and Rural North, 1800-2000, ed. J.T.H. Connor and Stephan Curtis (London: Routledge, 2016), 129-51, 260-5; and Gary L. Saunders, Doctor Olds of Twillingate: Portrait of an American Surgeon in Newfoundland (St. John's: Breakwater, 1994). While suggestive but not conclusive, it is noteworthy that the American Dr. Robert H. Coodwin, who is recorded as performing sterilizations in St. Anthony, also practiced in Twillingate around 1933. 
to curtail her activities with "boys and men." And in the instance of the woman with "no morals" who may have survived through prostitution, it may well have been a boon for her to have known that she had been sterilized. The logic of eugenics becomes convoluted in so many ways.

The notion of informed consent understood broadly is critical in this discussion. Certainly, it would be inappropriate to apply a current understanding of this concept to the period under study (and even today it remains a slippery ideal)..$^{6}$ Moreover, it would be another two decades before terms such as "social justice" and "human rights" would be meaningfully invented - and an even longer span of time before the concept of what is now understood to be "informed consent" was in general circulation. Nonetheless, as historian Susan Lederer has pointed out, during the first quarter of the 20 th century American doctors and hospitals were aware that legal action could be brought against them for assault if surgery was performed to which the patient did not previously agree (which also might include autopsies).57 For comparative purposes, in Canada roughly a decade later a hospitalized woman signed a consent, along with her husband, in which she clearly declared that she was "to be operated on for the purpose of rendering me sexually sterile because I have been competently advised and believe that pregnancy would endanger my life." 58 Thus there was the beginnings of a medico-legal understanding that peoples' bodies were their own property - certainly a nascent from of rights and social justice. While there might be good reason not to fault IGA doctors by current criteria, even by using those of their own era they can be seen to come up wanting. This form of informed consent was known and followed in St. Anthony in at least one other instance. In a case dating from 1934, which is contemporaneous with the sterilizations discussed, there is appended a document on IGA letterhead that is a patient consent. It states: "I [name redacted] of St. Anthony understand my complaint and herby give the doctors permission to operate on me according as they see best." It is dated and witnessed. Curtis, in his case notes, also wrote "Patient has signed a paper giving permission to use own judgment in treating her." ${ }_{99}$

\footnotetext{
56 Ruth R. Faden and Tom L. Beauchamp, A History and Theory of Informed Consent (New York: Oxford University Press, 1995).

57 Susan E. Lederer, Subjected to Science: Human Experimentation in America before the Second World War (Baltimore: Johns Hopkins University Press, 1995), 16-17.

58 Quoted in Georgina Feldberg, "On the Cutting Edge: Science and Obstetrical Practice in a Women's Hospital, 19451960," in Women, Health, and Nation: Canada and the United States Since 1945, ed. Georgina Feldberg, Molly LaddTaylor, Alison Li, and Kathryn McPherson (Montreal and Kingston: McGill-Queen's University Press, 2003), 134. 
Thus it can be proved that Curtis applied a double standard when operating. Forensically this may not be wholly damning, but it is highly problematic and troubling. Also troubling is the manner in which women were selected for sterilization. Again, fault may be found by contemporary standards. Whatever the failings and shortcomings were/are of IQ tests, their administration conferred an appearance of scientific objectivity and standardization. At a very general level they may have some validity and could be useful to evaluate people, no matter how crudely. In jurisdictions where surgical sterilization was state-sanctioned, the process typically involved a formal mental assessment that might often involve a committee. However, there is every indication that the only measure Curtis employed for surgical selection was his own subjective judgement. By all accounts Curtis took time to converse with his patients, from which he might have been able to gauge their mental acuity; but his approach was arbitrary. One suspects that if called upon in court to defend his decisions, even in his own era, Curtis would have been found lacking. And, given the asymmetric power relationship between a powerful man in a white coat and girls and women who typically were poorly socialized, there could be many good reasons for being slow to answer questions or for replying inappropriately. Both parties spoke English, but that does not mean they spoke the same language: a medical communication barrier existed then (and still does today in many Newfoundland outports) owing to dialects, level of literacy, and unequal educational achievement. ${ }^{60}$

At the very least, this examination of involuntary sterilization in St. Anthony adds to our broader understanding of the reach of eugenics during the early years of the 2oth century. On a very general level, Newfoundland's experience was similar to many other jurisdictions but on a much-reduced scale. It was gendered, as it was always men who sterilized women. There was a class component inasmuch as the likes of Curtis and Grenfell were of higher status and wielded much more power than orphans and the daughters and wives of local fishermen. But it is to be noted that eugenically oriented thinking and activities were not class-based per se in Newfoundland as there was no formal movement organized by middle class or elite groups to effect social control over those beneath them as with other dominions on the edges of empire. ${ }^{61}$ Yet a generalized caveat ought to be kept in mind: Grenfell's sympathy

60 On this language issue, see Gary L. Saunders, Doctor, When You're Sick You're Not Well: Forty Years of Outpatient Humour from Twillingate Hospital, Newfoundland (St. John's: Breakwater, 1998).

61 Paul, Stenhouse, and Spencer, Eugenics at the Edges of Empire. 
for race betterment and his belief in the superiority of the Anglo-Saxon. It is in no way reaching to impart to Grenfell, and probably Curtis, a belief that the women who were operated on were letting the "white side" down; by curtailing their ability to procreate a chock was placed to limit any additional sliding by Anglo-Saxons on a degeneracy gradient. Notwithstanding this, the eugenics practiced in St. Anthony appears not to have been race-based per se in that it did not target any particular visible minority. The number of cases identified is so small that generalizations are difficult; but it is safe to say that women and girls from Indigenous groups when they did enter hospital were not subject, for example, to the same mass sterilization programs that occurred in western Canada. Had Grenfell, Curtis, and the IGA wished to have done this, it would have been difficult yet not impossible. But to be clear, such was never any part of their overt agenda. That a "half-breed eskimo" was surgically sterilized probably spoke more to her particular idiosyncratic moral and health statuses as described than her racial background; admittedly, though, the question should perhaps be left hanging. To invoke Anna Stubblefield, a person such as this was in all respects "beyond the pale."62

What ought to be recognized as unique and of historiographic interest in the Newfoundland eugenics narrative is its transnationalism. Were it not for American doctors working for the IGA, it can be stated almost categorically that coerced surgical sterilization of women would not have been undertaken. The traffic in highly trained personnel, medical materiel, and ideas was on the whole highly beneficial for residents of the northern communities served by the IGA; but to again reference Carlson, a "bad idea" could also be shipped north among the myriad goods from the United States. As, for example, Kühl and Baker have shown, the exportation of American eugenic ideals to other jurisdictions was not uncommon; but the implementation processes were usually mediated in some way by the local importers. In so doing, this appropriation of ideas by individuals and organizations was not direct but was interpreted and shaped to suit the moral values and perceived social needs of the community. This process of what has been termed "inculturation" results in a new or hybrid form of what was introduced, giving it the sense that it was created and cultivated locally. ${ }^{63}$ The net effect is that in the case of eugenics,

62 See Anna Stubblefield, "'Beyond the Pale': Tainted Whiteness, Cognitive Disability, and Eugenic Sterilization," Hypatia 22, no. 2 (Spring 2007): 162-81.

63 Michelle Renshaw, Accommodating the Chinese: The American Hospital in China, 1880-1920 (New York and London: Routledge, 2005), esp. 10-11. For a comparative study of the importation and inculturation of American medical ideology and practices in Atlantic Canada in which American practitioners did not directly participate or guide, see 
for example, it loses its foreignness and becomes familiar, which aids in its acceptance and promotion. In Newfoundland, there was no inculturation process. Those who imported the ideas were the same people as those who implemented them; indeed, as these doctors were Americans and already resident in Newfoundland they likely would not subscribe to the fact that they were actually importers. The late 1920 s was a crucial period in terms of eugenics in the United States, it was wholly natural it would trigger events where they found themselves at that time. Under these circumstances, eugenics in Newfoundland becomes a sad story of American cultural imperialism. Newfoundland was probably unique in this experience, but what about other early-2oth-century medical missions in myriad "underdeveloped" regions worldwide where hundreds of American doctor-missionaries, perhaps some imbued with eugenic thought, practiced more or less unhindered? ${ }^{64}$ This also, no doubt, occurred in "settler-colonies-turned-new-nations"; one such example is Sir (Dr.) Māui Pōmare (1876-1930), a Māori doctor who trained at Kellogg's American Medical Missionary College in Battle Creek, Michigan. Pōmare became minister of health for New Zealand in 1923 and was an active promoter of eugenic thought, screening methods, and registries for the feebleminded. But he had to draw the line at surgical sterilization owing to his personal racial background and possible backlash from fellow Māori. ${ }^{65}$

How best to assess this whole topic historically? As historian Angus McLaren wrote, historians ought not to "condemn" those who promoted and/ or practiced eugenics; rather it is our goal to "understand what there was in the eugenics message that seemed to make good sense to many ... preoccupied by what they took to be the dangers of racial inefficiency, social inadequacy, and ill health." ${ }^{\prime 66}$ Nevertheless it often requires some degree of authorial cognitive dissonance to grapple with any objective historical interpretation of eugenics, which is why historians often tend to distance themselves from their writings on this topic, as alluded to in the introduction to this article. Historical and moral presentism can get in the way of understanding a historical process if we "back write" current values and mores onto the past. The current

Jane Jenkins, "A Little East of Eden: Re-Placing Canada's Public Health," Journal of Canadian Studies 50, no. 3 (Fall 2016): 511-37.

64 David Hardiman, "Introduction," in Healing Bodies Saving Souls: Medical Missions in Asia and Africa, ed. David Hardiman, Clio Medica series no. 80 (Amsterdam: Rodopi Press, 2006), 16.

65 On Pōmare, see Hamish G. Spenser, "Eugenic Sterilization in New Zealand: The Story of the Mental Defectives Amendment Act of 1928," in Paul, Stenhouse, and Spencer, Eugenics at the Edges of Empire, 87-9, and John Stenhouse, "Undesirable Bill's Undesirable Bill: William Pember Reeves and Eugenics in Late-Victorian New Zealand," in Paul, Stenhouse, and Spencer, Eugenics at the Edges of Empire, 136.

66 Angus McLaren, Our Own Master Race: Eugenics in Canada, 1885-1945 (Toronto: McClelland \& Stewart, 1990 ), 9. 
furore over monuments and statues that have been associated with slavery and white supremacy - including those commemorating the US Civil War, British colonialism, and, closer to medical history, that of J. Marion Sims, the "father" of gynecological surgery who experimented on enslaved black women - is a case in point. ${ }^{67}$ A propos that debate, should the larger-than-life statues of Sir Wilfred Grenfell that stand outside Confederation Building (the Newfoundland and Labrador provincial legislature) and also in front of the Grenfell Heritage Properties and Grenfell Interpretation Centre in St. Anthony be quietly removed? ${ }^{68}$ Ought the Charles S. Curtis Memorial Hospital in St. Anthony reconsider its name? Any unthoughtful rush toward censure or calls for rehabilitation, however, ought to be resisted or at least tempered. While we may exhibit moral superiority over previous generations with respect to eugenic sterilization as expressed in phrases such as "How could they have done such a thing?" and "What were they thinking?" it is sobering to realize that coerced sterilization continues in our so-called enlightened times. ${ }^{69}$ Most recently, even in Canada in 2015, many indigenous women in Saskatchewan were forcibly sterilized after giving birth in hospital..$^{70}$ As history is complex, responses to it must not be simplistic. The past may well be a foreign country and at times an uncomfortable place, but its existence must be recognized and dealt with. Moreover, despite claims of insular exceptionalism,${ }^{71}$ Newfoundland in the past, both for good and for ill, appears to have been more connected to the socio-medical mainstream than has been previously acknowledged.

67 DeNeen L. Brown, "A surgeon experimented on slave women without anesthesia. Now his statues are under attack," 29 August 2017; see https://www.washingtonpost.com/news/retropolis/wp/2017/08/29/a-surgeon-experimented-onslave-women-without-anesthesia-now-his-statues-are-under-attack/?utm_term=.3bd152beb115. See also Durrinda Ojanuga, "The Medical Ethics of the 'Father of Gynecology,' Dr. J. Marion Sims," Journal of Medical Ethics 19, no. 1 (1993): 28-31; L. Lewis Wall, "The Medical Ethics of Dr. J. Marion Sims: A Fresh Look at the Historical Record," Journal of Medical Ethics 32, no. 6 (June 2006): 346-50; and Ginia Bellafante, "The Statutes are Banished, but the Attitudes Persist," New York Times, 22 April 2018. Recently, a decision was made to relocate Sims's statue; see http://www1.nyc. gov/site/monuments/index.page.

68 Grenfell Historic Properties, "About Grenfell Interpretation Centre, St. Anthony, Newfoundland," https://www. grenfell-properties.com/photos.php\#rightcoltop.

69 Priti Patel, "Forced Sterilization of Women as Discrimination," Public Health Reviews 38, no. 15 (2017): 1-12, https:// publichealthreviews.biomedcentral.com/articles/10.1186/s40985-017-0060-9; Elena R. Gutiérrez, "Policing 'Pregnant Pilgrims': Situating Sterilization Abuse of Mexican-Origin Women in Los Angeles County," in Feldberg, Ladd-Taylor, Li, and McPherson, Women, Health, and Nation, 379-403.

70 See Yvonne Boyer and Judith Bartlett, External Review: Tubal Ligation in the Saskatoon Health Region: The Lived Experience of Aboriginal Women, 2017, https://www.scribd.com/document/354905632/Tubal-Ligation-ExternalReview; https://thestarphoenix.com/news/national/women-pressured-to-have-tubal-ligations; and https://www.cbc. ca/news/canada/saskatchewan/sask-indigenous-women-file-lawsuit-claiming-coerced-sterilization-1.4348848.

71 David Lowenthal, "Canadian Historical Nonchalance and Newfoundland Exceptionalism," Acadiensis XLVI, no. 1 (Winter/Spring 2017): 152-62. 
J.T.H. CONNOR est professeur d'histoire de la médecine à l'Université Memorial. Il a publié plusieurs livres dont Doing Good: The Life of Toronto's General Hospital (Toronto, University of Toronto Press, 2000) et codirigé la publication d'un recueil d'essais intitulé Medicine in the Remote and Rural North, 1800-2000 (Londres, Routledge, 2016). Il a aussi signé des articles dans des revues américaines, britanniques et canadiennes consacrées à l'histoire de la médecine.

J.T.H. CONNOR is a professor of medical history at Memorial University. His books include Doing Good: The Life of Toronto's General Hospital (Toronto: University of Toronto Press, 2000) and a coedited collection of essays entitled Medicine in the Remote and Rural North, 1800-2000 (London: Routledge, 2016), and articles of his have also appeared in American, British, and Canadian history of medicine journals. 